\title{
Portugal, Anthropology in
}

\author{
CRISTIANA BASTOS AND JOSÉ MANUEL SOBRAL \\ Universidade de Lisboa, Portugal
}

\section{Overview}

With the double purpose of updating a scattered database and achieving an accurate profile of its constituency, in 2015 the Associação Portuguesa de Antropologia (Portuguese Anthropological Association) launched an online questionnaire to be filled in by people who identified themselves as anthropologists. Nearly 1,000 people responded, both nationals and expatriates-not an insignificant number for a small country with a relatively recent professionalization of social scientists. An analysis of the data that were gathered gave a clearer view of who the respondents were, where they worked, how much of their current activity was related to their training in anthropology, how many of them held academic positions, whether stable or temporary, to what extent they circulated between jobs, countries, government work, nonprofit, community engagement, international agencies, self-employment, unemployment, what their scientific interests were and their social engagements, as well as other relevant matters.

Anthropology was already known to be a vibrant community that had grown mostly since the mid-1980s. This entry will address how it emerged and expanded, its roots and ancestors, and how it relates to other national and international intellectual traditions. Also addressed will be its relations to other disciplines, its main institutions of research and teaching (past and present), and the political contexts in which they developed, and the discipline's current fragilities and strengths. The underlying theses are the following:

1. Anthropology as a social science could not really flourish in Portugal until the 1970s and 1980s. The discipline has existed since the late nineteenth century, following different institutional paths: while physical anthropology had an uninterrupted history as a specialty within the natural sciences, the branches of anthropology that address culture, language, and society had a more complex and interrupted existence. In spite of the fact that there were remarkable ethnologists, philologists, and folklorists-plus colonial ethnographic surveys conducted by administrators with anthropological training-during a large portion of the twentieth century, the right political conditions did not exist for the exercise of critical social analysis and most approaches to ethnographic and anthropological subjects did not develop a sustained theoretical component.

2. The intellectual freedom following the demise of the 1933-74 dictatorship provided an appropriate environment for the launching of a local-based field of critical social sciences. The field benefited from the return of scholars who had been trained 
abroad (some of them in political exile) and also from the presence of international scholars who settled in Portugal in the late 1970s and 1980s.

3. The economic boost experienced in Portugal after entering the European Union in 1986 allowed for the expansion of the higher-education system. This had a direct positive impact on the discipline of anthropology by creating academic jobs for locally trained anthropologists, allowing them to teach regular courses, promote outreach, engage in local initiatives on culture, heritage, social action, in addition to exposing a large number of students and the public to anthropology.

4. During the years of relative prosperity (between the late 1990s and early 2000s) there were proactive, government-sponsored policies to promote the sciences in Portugal, which included the support of advanced training, doctoral fellowships, research fellowships, and flexible academic positions directly contracted by research centers, parallel to conventional university careers. In that context, the field of anthropology matured, expanded, and achieved international prominence.

5. Given that the expansion of anthropology relied on public funds, the field-like most other sciences-suffered dramatically with the governmental budget cuts and general austerity imposed in the aftermath of the 2007-8 global financial crisis. Anthropologists now face new challenges to their creativity and ability to respond to critical situations.

\section{Ancestors and early institutions}

Combining the Romantic tradition and a positivist approach to the world, much like other European scholars at the time, numerous nineteenth-century Portuguese intellectuals engaged in the study of their people and roots. They referred to Johann Bachofen, Lewis Morgan, Max Müller, and other pioneers of anthropology as a basis for their inquiries into and reflections on the Portuguese people and their ancestors, customs, folklore, legends, myths, fairy tales, archaeology, rituals, festivities, religious cults, linguistic forms, dialects, family types, and physical constitutions.

Among the best known of those authors were: Teófilo Braga (1843-1924), a polymath who cultivated a wide range of interests that included ethnography, philosophy, and literary history, and who became an influential politician in the First Republic (1910-26), serving as prime minister in 1910-11 and as president in 1915; Adolfo Coelho (1847-1919), a renowned educationist, philologist, and ethnographer who worked extensively on linguistic matters and on folktales; Consiglieri Pedroso (1851-1910), a polyglot philologist and ethnographer who systematically studied myths and folktales; Leite de Vasconcelos (1858-1941), who left the medical profession to pursue the archaeological, philological, geographic, and ethnographic interests that led, among his many works, to the multivolume Etnografia Portuguesa (Portuguese Ethnography, 1933-88) and to the foundation of the ethnographic museum of Belém in 1893; and Rocha Peixoto (1866-1909), a scientist, archaeologist, and ethnologist who authored numerous works on material culture and other subjects. Peixoto taught at the famous Polytechnic Academy of Porto while the others all taught in the Curso Superior de Letras (Bachelor of Letters) of Lisbon or its successor, the Faculty of 
Letters. They addressed the themes of the moment, such as language, ethnicity, uses of land, material modes of subsistence, arts and crafts, traditional cures and prayers, religious rituals, oral literature, and comparative mythology. Being cosmopolitans who read and followed what was published by their French, German, British, and Italian counterparts, and who also published abroad, those scholars brought to Portugal major international debates concerning the primitive family, Indo-European mythology, and the speculations over the ethnogenesis of the European peoples (Leal 2000, 30-31).

That depth of involvement was not maintained in the following generation, which focused more on local folk traditions and disengaged from international discussions. The vigor that had mobilized the late nineteenth- and early twentieth-century intellectuals echoed through the First Republic (1910-26) but did not last through the authoritarian years (1926-74) that followed. Physical anthropology gained institutional importance while ethnography lost its public impact, much of it being carried forward only by local amateurs.

Physical anthropology had emerged in Portugal within the same circles as ethnography, yet they had distinct institutional histories. Among the first who publicized the new discipline of physical anthropology was the historian, economist, and public intellectual Oliveira Martins (1845-94). Like many others at the time, he endorsed the belief on a hierarchization of human races-an assumption widely shared in Europe before the devastating outcomes of Nazism.

The institutional origins of physical anthropology in Portugal date back to the 1880s. Lisbon hosted the ninth International Congress of Anthropology and Prehistoric Archaeology in 1880. In 1885, the chair of anthropology, human paleontology, and pre-historical archaeology was created in the University of Coimbra by Bernardino Machado (1851-1944), a mathematician and politician who would become president of the republic twice (1915-17; 1925-26). The chair covered physical anthropology, anthropometry, raciology, studies of human evolution and prehistory. Ethnology, or cultural anthropology (including colonial ethnography focused on the Portuguese colonies), remained peripheral in Coimbra until very late on. Nevertheless, Coimbra had a laboratory museum and, from 1893, an ethnographic museum, later termed an ethnological museum, which hosted important collections of colonial artifacts from eighteenth-century Brazil, Africa, and Macau.

Coimbra, Porto, and Lisbon shared the action in different ways. Until the end of the monarchy (1910), Coimbra was the sole university system in Portugal. Both Lisbon and Porto had colleges and schools of higher education but only in 1911 were their colleges unified as universities.

Lisbon, the capital, also hosted scientific societies that had been created to promote knowledge in the context of the Enlightenment, such as the Academy of Sciences, founded in 1779, or, in the context of intra-European competition for colonial empires, such as the Geographical Society, founded in 1875. Those societies sponsored research expeditions to the lesser known areas of the country and colonies, published memoirs and reports, functioned as centers of archiving and analysis for the correspondents who compiled data in different sites, and amassed vast collections of colonial artifacts.

Since the 1880s, the city of Porto had been a very important place in the rise of Portuguese anthropology in its different components, including physical anthropology, 
archaeology, and ethnography. The foundation of the University of Porto in 1911 further enhanced the development of the discipline by providing formal teaching on its subjects plus having an anthropological museum and a laboratory. These were the institutional bases of the "Porto's School of Anthropology," a group headed by the notorious physician, physical anthropologist, and archaeologist Mendes Correia (1888-1960), who was also the founder of the Portuguese Society of Anthropology and Ethnology (Sociedade Portuguesa de Antropologia e Etnologia) in 1918. Mendes Correia was a racialist who dreaded miscegenation and promoted an ethnoracial nationalism that linked the Portuguese with the half mythical prehistorical people of Lusitania (Matos 2006; Pereira 2005).

Several journals testify the importance of the ethnological, linguistic, and archaeological research at that time: Revista de Etnologia e Glotologia, promoted by Adolfo Coelho; Anuário para o Estudo das Tradições Populares, promoted by Leite de Vasconcelos, Portugália (1899-1908), whose main editor was Ricardo Severo, an engineer and archaeologist; Revista Lusitana (1889-1943), again founded by Leite de Vasconcelos, and Trabalhos de Antropologia e Etnologia (since 1918), sponsored by the Portuguese Society of Anthropology and Ethnology (Sociedade Portuguesa de Antropologia e Etnologia).

\section{Nation and empire}

The early Portuguese anthropologists appeared more interested in knowing and writing about their own people, or peoples, their ancestors, and the roots of the Portuguese nation than in the peoples affected by empire. Naturally, some authors suggest that Portuguese anthropology should be seen as of the "nation-building" type, rather than "empire building," in the typology proposed by George Stocking (Leal 2006). However, others have argued that there were numerous less visible yet meaningful works and authors addressing colonial issues (Pereira 1998; Roque 2001) and that the dichotomy does not really apply to Portuguese anthropology (Viegas and Pina-Cabral 2014), given that in this context nation and empire were intertwined projects.

The early Portuguese anthropologists were indeed involved in the search for their own people, as epitomized by the rural poor, who, as the most removed from the cosmopolitan and literate urban elites in which the ethnographers had grown, were regarded as the guardians of authentic traditions (Vasconcelos 1933, 1:18). It was within their material culture and orally transmitted practices and traditions that ethnographers searched for traces and evidence of the distinctiveness of the Portuguese. In sum, by collecting a variety of items deemed to be the expressions of Portuguese traditions, knowledge, and behavior, they were the agents of a "cultural objectification" of the nation. They acted as early cultural anthropologists, although their work was not entirely free of a naturalized and racialized understanding of human diversity. Physical anthropology was then highly influential, both in giving a scientific status to racial segregation and in promoting anthropometric studies on specific populations within Portugal and the colonies (Matos 2006; Roque 2001). 
At this point, we should note the nationalist passion of the early Portuguese ethnographers. They were infused with a nationalist worldview committed to the revival of the former glories of the Portuguese nation; there was a pervasive mood that Portugal was in decline and the building of the African empire was seen increasingly in the late nineteenth century as an indispensable part of that national revival-in the competing context of the "age of empire" in which racialized nationalisms developed.

Although the Portuguese claimed vast territories in Africa, the fact was that before the twentieth century they had little control and knowledge about those places and the people who lived there. Ethnographic research in the colonies was then conducted on a relatively modest scale, with occasional collections of artifacts and the participation in colonial exhibits toward the end of the nineteenth century-including the promotion of the Exposição Insular e Colonial Portuguesa (Portuguese Insular and Colonial Exhibition) in Porto, 1894. Ethnographic and anthropometric data were collected by researchers, military officers, and colonial administrators, at times sponsored by the Geographical Society. It was also in the Lisbon Geographical Society that the Colonial School was established in 1906, to be turned by the republican government into a distinct institution for the preparation of colonial state agents. This was an important center for data collection, as the students were required to present a monograph on a relevant colonial topic. Whether in the context of the Colonial School or colonial medicine, systematic research in the colonies would only happen later in the twentieth century. Further into the twentieth century, the Diamond Company of Angola would directly sponsor research in the district of Dundo (in northeast Angola) and have its own ethnographic museum and biomedical services (Porto 2009).

\section{The mid-twentieth century}

The authoritarian regime of the Estado Novo (1933-74), inspired by fascism, abolished liberal democracy and also the freedom of the press. Academics deemed hostile to the regime were expelled from the universities. All intellectual endeavors were now strictly controlled. Ethnography went into decline, with the gradual disappearance of the members of the cosmopolitan generation that began publishing in the late nineteenth century. Leite de Vasconcellos (1858-1941), a founding figure both of Portuguese archaeology and linguistics-he had earned a $\mathrm{PhD}$ on the varieties of the Portuguese language at the University of Paris in 1901-retired from the University of Lisbon in 1929. No one of his stature was there to replace him and, although ethnology continued to be taught in the departments of geography in Lisbon and Coimbra, most of the ethnographic work acquired a parochial tone; it celebrated the peasantry as embodying tradition, something in tune with the regime's image of a hardworking, deferential, and staunchly Catholic people; there was no place for inequality and conflict in those views. Sociology was practically nonexistent under the authoritarian regime.

Biological and physical anthropology continued to be taught because it did not raise sensitive political questions and its most eminent figures, such as Mendes Correia (1888-1960) in Porto and Eusébio Tamagnini (1880-1972) in Coimbra, were members of the regime's political elite-Correia would be the director of the Colonial School and 
president of the Geographical Society; Tamagnini a minister in the government. The discipline was infused with racial theory and both Correia and Tamagnini were white supremacists and hostile to miscegenation. The research they encouraged involved mainly anthropometrics and the study of the "blood groups" of the Portuguese and the colonized populations; in the colonies, the main purpose was the study of the value of the Africans as a workforce (Pereira 2005).

The colonies and their peoples appeared in the public domain as the subjects of organized, impactful displays such as the Portuguese Colonial Exhibition, in Porto 1934, and the Exhibition of the Portuguese World, in Lisbon 1940. The latter celebrated the indissolubility of the nation and of the empire; the date also referred back to the foundation of the kingdom of Portugal around 1140 and the recovery of its independence from Spain in 1640. Mendes Correia was deeply involved in both events. His widely publicized book As raças do império (The Races of Empire) was published in 1943 (Matos 2006). Contrary to what was later depicted by Lusotropicalist writers, racial segregation was endorsed by the authors of the regime and enforced in the colonies. Things would only change, albeit very slowly, after World War II.

The general discrediting of racialism in the aftermath of World War II met with resistance, including in Portugal. Change came gradually during the 1950s, coinciding with an increasingly clear separation between physical anthropology-renamed biological anthropology - and ethnology, also designated as cultural anthropology. One person epitomized that change and became the most influential anthropologist: António Jorge Dias (1907-73). Mendes Correia, who had been the dominant figure of Portuguese anthropology until then, became a supporter of Dias's career and recognized the political relevance of the social sciences, particularly the importance of "colonial social scientists" in a time when the anticolonial movements threatened the political order (Pereira 2005, 233).

Jorge Dias studied English and German literatures and languages in Portugal and went on to study for a doctorate in ethnology (Volkskunde) in Germany, which he completed in 1944. Although his supervisor was a member of the Nazi party, this did not impinge on Dias's dissertation, which was dedicated to the social life in the mountain village of Vilarinho da Furna in northwest Portugal (Dias 1948). Dias was a fierce opponent of racism all through his life.

Dias claimed to pursue the ethnographic enterprise of studying the Portuguese people that had begun in late nineteenth century and at the same time he introduced in Portugal, in limited ways, elements of modern anthropology. As an ethnographer, he pursued with his team-Ernesto Veiga de Oliveira, Benjamim Pereira, Fernando Galhano, and occasionally also his wife Margot Dias-a wide program of research that had its richest expression in the field of material culture linked to agriculture (Oliveira, Galhano, and Pereira 1976). His main collaborators proceeded with their research on folk culture for many years after his death. As an ethnographer he identified with the program of the Commission des Arts et Traditions Populaires (Commission for Arts and Folk Traditions), which was created in 1928, the predecessor of what is nowadays SIEF (International Society for Ethnology and Folklore), of which he was a secretary general between 1954 and 1957. 
The anthropology that Dias introduced in Portugal was his own version of cultural anthropology, mainly inspired by what had been pursued in Germany and North America. He was not inclined toward social anthropology's functionalist theories, which he considered to be overly concerned with the workings of social systems, disregarding history and not paying enough attention to culture and to individuals. He quoted German and North American authors like Richard Thurnwald, Wilhelm Muhlmann, Franz Boas, Robert H. Lowie, Melville J. Herskovits, Alfred L. Kroeber, Robert Redfield, Margaret Mead, and especially Ruth Benedict, whose Patterns of Culture and The Chrysanthemum and the Sword inspired Dias's essays on peasantry and on the Portuguese national character (Leal 2006, 149-66; Sobral 2007).

To fully understand the role played by Dias, one has to account not only for his ethnographic and anthropological training but also for his political-ideological views and the historical circumstances that backgrounded his career. He adopted from Brazilian sociologist-anthropologist Gilberto Freyre (1900-1987) a Lusotropicalist view of empire and, very probably, from Brazilian historian Sérgio Buarque de Hollanda the notion of a noncapitalist character of the Portuguese colonial ventures. Drawing on those concepts, Dias built a characterization of the Portuguese and their seaborne expansion as noncapitalist and without the stain of racial prejudice. This accorded well with the later phase (from the 1950s to 1960s) of the Estado Novo's political rhetoric, which presented the Portuguese as unique colonizers who differed from all others by being nonracist and recognizing colonial subjects as equals-hence legitimizing opposition to the African demands for emancipation. However, Dias was not free of contradictions and the cultural relativism he so promptly adopted clashed with the claim of the civilizational superiority of Christianity the Portuguese had spread around the world, a motto of the national-Catholic discourse of the Portuguese government that Dias also adopted (Sobral 2007). Dias in his late thirties had rebelled against his own bourgeois predicament and invested the subjects of his community studies_Vilarinho da Furna: Uma aldeia comunitária (Vilarinho da Furna: A Communalist Village, 1948) and Rio de Onor: Comunitarismo agro-pastoril (Rio de Onor: Agropastoral Communalism, 1953)—with superior human qualities; the self-elected local institutions of those communities were presented as a model of democracy. This view would contribute to a long fascination exerted through his monographs in the imagination of many people afterwards. On the other hand, Dias was a man of the establishment. He was trusted by the government with the most important expedition of Portuguese anthropology in the colonies, among the Macondes who lived along the northern border of Mozambique. This field trip occurred at the same time-the second half of the 1950s-as the government put an end to the colonial physical anthropology research conducted by Santos Junior (Pereira 2005, 235). Dias's research among the Macondes resulted in a four-volume and widely illustrated conventional monograph, Os Macondes de Moçambique (The Macondes of Mozambique, 1964-70), with much detail on tradition and little mention of the processes of change that most anthropologists working in Africa at the time addressed, let alone a reference to the involvement of the Macondes and other Mozambican communities in anticolonial movements (West 2004). Dias kept his own personal interest on change hidden away in the confidential reports addressed to the authorities, 
which demonstrate the political and ideological underpinnings of his research in Mozambique in close affinity with Estado Novo colonial policies (Pereira 1998). Those reports also testify how he saw the racist practices of the colonists in Mozambique that so totally contradicted the Lusotropicalist credo that he and the authorities endorsed.

Dias's increasingly influential role allowed for a limited advancement of the teaching of cultural anthropology, in particular in the Instituto Superior de Ciências Sociais e Política Ultramarina (ISCSPU; Higher Institute of Social Sciences and Overseas Politics), which had evolved from the old Colonial School. While at ISCSPU, Dias was a full professor of cultural anthropology. At that time, students of colonial administration were required to produce monographs and some of them elaborated lengthier works in the aftermath of their administrative careers, such as António Carreira for Cabo Verde and Augusto Mesquitela Lima for Angola. However, critical commentaries were not allowed under the authoritarian regime of the Estado Novo, which forbade free discussion or any kind of debate over the social and political situation in the colonies, where armed insurrection had begun at the start of the 1960s.

Dias also founded the Centro de Etnologia e Antropologia Cultural (CEAC; Center for Ethnology and Cultural Anthropology) and later the Museum of Ethnology, which would expand its activities with the coming of the democratic regime in 1974. Dias's disciples followed their own academic path or continued the work he had started. Manuel Viegas Guerreiro (1912-97), a member of the research mission to the Macondes of Mozambique, became a professor of ethnography at the Faculty of Letters in Lisbon. Other important coworkers and disciples of Dias were those who formed the team of Etnologia Peninsular (Peninsula Ethnology) -Ernesto Veiga de Oliveira (1910-90) and Benjamim Pereira (b. 1928), in particular-and continued the ethnographic surveys in the 1970s and afterwards. The newly built Museum of Ethnology (for which Dias had successfully lobbied but did not live to make use of) in Restelo, equipped with a specialized library and first-class exhibit rooms, became a hub that attracted ethnographers, students, collectors, artists, and scholars from around the world.

In parallel to the activities of Dias's group, there were important surveys in the area of ethnomusicology, such as those of Michel Giacometti and of Fernando Lopes-Graça, and in the area of vernacular architecture, such as the massive survey promoted by the National Union of Architects between 1955 and 1960.

\section{A new cycle: Contemporary anthropology}

While the Portuguese ethnologists of the mid-twentieth century produced ethnographic surveys and monographs but no theorization that contributed to international scholarship, there were international anthropologists conducting research on different sites in Portugal and in the colonies. Brazilian scholar Gilberto Freyre developed Lusotropicalism - the theorization of a Portuguese vocation to intermingle with "tropical peoples" and create more benign modes of colonization-while on a tour of the Portuguese colonies in the 1950s; the doctrine was not promptly embraced by the Portuguese authorities but was later used as a basis to justify the ruling over 
Africa, and Freyre became an officially endorsed author. His critic Marvin Harris, from Columbia University in New York, visited Mozambique and had students working in different settings, including Portugal (Oliveira 2014, 309). Also from the United States, Deirdre Meintel worked on race, culture, and colonialism in Cape Verde in the 1970s. Joyce Riegelhaupt, another American anthropologist, had conducted her research in the outskirts of Lisbon, accounting for the relationship between communities and between the communities and the city. French anthropologist Colette Cailler-Boisvert conducted fieldwork in a rural mountain community in northern Portugal. Pierre Sanchis, also from France, did his major research in Portuguese popular religiosity. José Cutileiro, a Portuguese-born Oxford graduate, addressed the social stratification of the Alentejo and the underlying class conflict in a monograph that became a local classic of social anthropology.

Leal (2006) uses the pastoral/counterpastoral opposition to depict the contrasting monographs of Dias, which idealized agro-pastoral mountain societies, with communal uses of land and small properties, and Cutileiro, who addressed the counterpastoral topics of class conflict and social inequities in the plains of southern Portugal (Alentejo), where landownership on a large scale prevailed. Most other international works would also be counterpastoral, from Riegelhaupt's work to a whole set of research on Minho in the 1970s and 1980s, including the work of Caroline Brettel on migration, women, and men, of Sally Cole on women in a fishing community, of Jeffrey Bentley on farming and inequalities, and, later, of Fabienne Wateau on water conflicts. As they worked through the theory with ethnographic data collected in Portugal, they significantly contributed to the bibliography of reference material for Portuguese anthropologists interested in their own country. Numerous other international anthropologists also worked in Portugal but with less impact on local anthropology (Branco 2014).

As the Estado Novo and its colonial regime came to an end between 1974 and 1975, Portugal became a place of convergence for social scientists from different backgrounds, many of whom had been trained abroad, such as Joaquim Pais de Brito, João de Pina-Cabral, Raul Iturra, Brian O’ Neill, Robert Rowland, José Carlos Gomes da Silva, and others. The degree on anthropological and ethnological sciences offered at ISCSPU, now renamed ISCSP (as the "U" stood for Ultramarina, or overseas, a euphemism for colonies that was expunged after 1974), was radically transformed and inspired a few in the next generation anthropologists-João Leal, Jorge Freitas Branco, Rosa Perez, José Gabriel Pereira Bastos, and others. That institution weeded out professors who had supported the colonial regime before becoming so radical that the government closed it down; it reopened in the 1980s with a compromise between the new and the old perspectives. In the meantime, a new degree in social and cultural anthropology became available at FCSH-UNL (Faculty of Human and Social Sciences of the New University of Lisbon) in 1978, recruiting scholars trained both at ISCSP and abroad-mostly in Belgium and France. French structuralism, also popular in other disciplines at the time, pervaded as the most influential theory in the early years of that department. Later, and still in the context of a rapid expansion of the university system, the convergence of a few anthropologists at ISCTE (Higher Institute for Enterprise ad Labor Sciences), originally founded as a college for the teaching of economics, 
business, and sociology, led to the creation of a new department and degree in anthropology, this time with a stronger (but not exclusive) influence of British-inspired social anthropology. The University of Coimbra, where physical anthropology never ceased to be taught, also created in 1994 a new degree that combined its tradition in biological anthropology with new perspectives coming from social and cultural anthropology. The novel Universities of Minho (UM), in Braga, and of Trás-os-Montes (UTAD), in Vila Real, also recruited anthropologists and formed either distinct departments or prominent sections. UTAD created a degree in applied anthropology and development in its campus of Miranda do Douro. In Porto, the private University Fernando Pessoa also offered a degree in anthropology. Throughout the country, in the new universities and polytechnics, there were courses in anthropology inserted in different programs. The Institute of Social Sciences, an advanced research center at the University of Lisbon, recruited several anthropologists and would later offer masters' and doctoral degrees.

Much of the work of the new generation focused on doing "anthropology at home," partly inspired by the works of Dias and Cutileiro, partly in tune with what was being done in other countries, and also as part of a widespread global interest in the study of peasant societies, shared by sociologists, historians, and anthropologists, and related to the political moment of the country. The end of the authoritarian regime in 1974 was followed by revolutionary change, entailing the nationalization of banking and of the major industrial corporations, a radical agrarian reform in the south, and support for the independence of the colonies. All of this was infused with a wish, tinged with romanticism, to discover and promote a people whose wellbeing legitimated the attempts to build a new democratic and socialist society. Like the early generation of the nineteenth century, anthropologists turned first to the rural poor and their communities.

Soon enough there were anthropological studies in several regions, almost all located in the rural countryside and exploring a variety of themes, from spatial patterns to material culture and property, family and social reproduction, religion, worldviews, festivities and ritual, social organization, social class and conflict, and gender. The rural north attracted the majority: João de Pina-Cabral and Alice Geraldes for Minho, Brian O’Neill and Joaquim Pais de Brito for Trás-os-Montes, and José Sobral and Raúl Iturra for Beira Alta; toward the south, there were Armindo Santos for Beira Baixa, Jorge Freitas Branco for the islands of Madeira, João Leal for the Azores, Cristiana Bastos for the Algarve, Miguel Vale de Almeida for the Alentejo, and Graça Cordeiro for Lisbon-to mention just the first wave of new works on the country. The volume Lugares de aqui (Places of Here; O’Neill and Brito 1991) provides a glimpse of that moment, followed by the comprehensive collection $O$ vôo do arado (The Flight of the Plow; Brito, Baptista, and Pereira 1996).

At the turn of the twenty-first century, Portuguese anthropology was in overdrive. While some of the achievements of its expansion were short lived, such as the BA degrees in anthropology offered in Porto and Miranda do Douro and the elective offered in high school, others improved: research centers achieved international prominence, attracting many scholars and students, developing first-class research and publications; the three BAs in cultural and social anthropology offered in Lisbon 
(FCSH-UNL, ISCTE, ISCSP) were followed by the offer of a number of MA degrees in different subspecialties and with solid doctoral programs (also in ICS, the Institute of Social Sciences of the University of Lisbon); Coimbra kept its combined vocation for biological and social and cultural anthropology. The CEAS (Center for Studies in Social Anthropology), originally founded in ISCTE in the mid-1980s, evolved into the CRIA (Anthropological Research Network Center), a strong and productive network of researchers associated with different universities (ISCTE, FCSH, Minho, Coimbra, and others). The cluster of anthropology researchers at ICS, an interdisciplinary social sciences institute, also expanded in terms of research projects, publications, and outreach. The CIAS (Research Center for Anthropology and Health) in Coimbra matured as a reference point in biological anthropology and archaeology. Other centers, whether hosted in museums, scientific societies, or universities, also conducted anthropological research and contributed to the field. The main journals that grew in prominence were Etnográfica (social and cultural anthropology), Antropologia Portuguesa (biological and social/cultural anthropology), Trabalhos de Antropologia e Etnologia (founded in 1919), and Antropológicas.

The scope of research topics and contexts expanded outside the national borders and improved in diversity and sophistication within. To outline a sample, necessarily incomplete and counting only works published until 2010, there had been research outside Portugal on Gujarat villages (Rosa Perez), Moroccan cities (Maria Cardeira da Silva), sub-Saharan African settings (Manuel Areia, A. Yanez Casal, J. Fialho Feliciano, Clara Carvalho, Manuel J. Ramos, Fernando Florêncio, Manuela Palmeirim, Amélia Frazão-Moreira, Nuno Porto, F. Ribeiro), ethnicities and kinship in China (João de Pina-Cabral, Gonçalo D. Santos), Azorean diaspora in the Americas (João Leal), Brazilian indigenous groups (Susana Matos Viegas), transnational identities and practices (Susana T. P. Bastos and José G. P. Bastos, Luís Batalha, João Vasconcelos, José Mapril, Marta Rosales), science networks (Cristiana Bastos, Nélia Dias), death rituals (Clara Saraiva), and, with a renewed approach to Portuguese issues, there were works on national identity (Luís Cunha, José Sobral, António Medeiros), borders (Fátima Amante, Paula Godinho, Humberto Martins), memory and heritage (Paula Godinho, José Sobral, Elsa Peralta), cultural policies (Vera Marques Alves), religious communities (Marina Pignatelli, Pedro Pereira, Ramon Sarró and Ruy Blanes, Clara Saraiva), labor (Paulo Granjo, Emília M. Marques), financial elites (Antonia P Lima), prisons and confinement (Susana T. P. Bastos, Manuela I. Cunha), soccer (Daniel Seabra), tourism (Paula Mota Santos, Luís Silva, Xerardo Pereiro), critical museum studies (Nuno Porto, Nélia Dias), fairy tales (Francisco Vaz da Silva), the history of anthropology (Frederico Rosa), and Portuguese anthropology (Rui Pereira, Jorge Freitas Branco, João Leal, Gonaçalo D. Santos), epistemology (Filipe Verde, Luís Quintais), environment (Ana Isabel Afonso, Jean-Yves Durand, Pedro Prista), surveillance (Susana Durão, Catarina Fróis), land reform and revolution (Margarida Fernandes, Sónia Vespeira de Almeida), fishing communities (Inês Meneses and Paulo Mendes, Francisco Oneto Nunes), spatial patterns and culture (Shawn Parkhurst), ritual and performance (Paulo Raposo), visual anthropology (Catarina Alves Costa), urbanities (Filomena Silvano, Teresa Fradique, Daniel Seabra Lopes, Paulo C. Seixas), health and illness (Cristiana Bastos, M Manuel Quintela, Elsa Lechner, Chiara Pussetti and 
Luís Silva Pereira), food and cuisine (Daniela Araújo, Vasco V. Teixeira, José Sobral, Nuno Domingos, Marta Rosales), ethnomusicology (Susana Sardo), and many other topics. And while the study of colonial issues was avoided for a long period in the new Portuguese anthropology, it would come back as a prime field, often in convergence with history, cultural, and postcolonial studies. Biological anthropology also renewed itself dramatically in the post-dictatorship decades, opening up to important research on primatology in Lisbon (Claudia de Sousa and Catarina Casanova). Yet Coimbra remains the benchmark in the teaching and research of biological anthropology and also in connection with archaeology and forensic medicine (Augusto Abade, Eugénia Cunha, Cristina Padez, among others). After 2010, the diversity and quality of works within the field expanded even further.

In the meantime, Portuguese anthropology spread among international circles, especially, although not exclusively, within the European Union and among the imagined community of Portuguese-speaking countries. Portuguese scholars were among the first members of the European Association of Social Anthropologists (EASA), which had its first biennial conference in Portugal in 1990, and Pina-Cabral, the convener, went on to become president of EASA between 2003 and 2004. The widespread Portuguese participation in its meetings and structures helped to facilitate the circulation of scholars and ideas throughout Europe. Later, the ERASMUS (European Region Action Scheme for the Mobility of University Students) Programme, a successful academic interchange project run by the European Commission, also led many students and faculty to circulate and develop international research teams. Throughout the decades, different preferential alliances emerged such as with Spain, the United Kingdom, France, and Italy, among others.

From the mid-1990s, a powerful connection with Brazilian anthropology also emerged, making possible an intensive circulation of anthropologists between the two countries for individual field research, for academic exchange, and for joint research projects (Bastos 2014; Viegas and Pina-Cabral 2014). Moreover, a few different platforms, such as social sciences conferences and funding programs, encouraged the circulation of social scientists who share the Portuguese language. This affected not only the intensification of the interchanges between Portugal and Brazil but also a multidirectional network linking social scientists from Mozambique, Cape Verde, Angola, and other countries. It is likely that this network also influences the frequency with which Portuguese anthropologists choose research sites related to the colonial history.

\section{Final note: Anthropology in times of austerity}

On the eve of the Eurozone recession, the prospects for Portuguese anthropology seemed bright. The field was diverse and dynamic; international young scholars and doctoral students enriched local anthropology, bringing in novel synergies. The different departments and research centers organized teaching and research while and the Portuguese Association of Anthropology, established in 1989, found its role 
in gathering consensus amid the diversity within the discipline and in organizing increasingly successful meetings.

However, the austerity measures introduced after the financial crisis of $2007-8$ greatly affected local scientific policies; funding for doctoral students, postdoctoral researchers, and research projects was drastically reduced. As national funding declined, or disappeared, researchers have had to apply to other sources in order to conduct their work, support students, and sponsor postdoctoral fellows. After decades of growth in intellectual maturity and internationalization, Portuguese anthropology is now facing difficult times and the trends portrayed are likely to take a backward step. While the community is affected, most of its members persevere in their efforts to keep anthropology, whether in the university or beyond its doors, as a vital contribution to the critical understanding of society.

SEE ALSO: Animism; Anthropology: Scope of the Discipline; Boas, Franz (1858-1942); Brazil, Anthropology in; Brazilian Association of Anthropology (ABA); Colonialism and the Museum; Coloniality of Power; Diplomacy and International Relations; European Association of Social Anthropologists (EASA); Evolutionism; Freyre, Gilberto (1900-1987); Indigeneity in Anthropology; Kroeber, Alfred L. (1876-1960); Mead, Margaret (1901-78); Nationalism; Postcolonialism; Power, Anthropological Approaches to; Thurnwald, Richard (1869-1954); United States, Anthropology in; World Anthropologies

\section{REFERENCES AND FURTHER READING}

Bastos, Cristiana. 2014. "A década de 1990: Os anos da internacionalização [The 1990s: Or the Years of Internationalization].” Etnográfica 18 (2): 385-401.

Branco, Jorge Freitas. 2014. "Sentidos da antropologia em Portugal na década de 1970 [Meanings of Anthropology in Portugal in the 1970s].” Etnográfica 18 (2): 365-78.

Brito, Joaquim Pais de, Fernando Oliveira Baptista, and Benjamim Enes Pereira, eds. 1996. O vôo do arado [The Flight of the Plow]. Lisbon: Museu Nacional de Etnologia.

Dias, Jorge. 1948. Vilarinho da Furna: Uma aldeia comunitária [Vilarinho da Furna: A Communalist Village]. Porto: Instituto de Alta Cultura.

Dias, Jorge. 1953. Rio de Onor: Comunitarismo agro-pastoril [Rio de Onor: Agropastoral Communalism]. Porto: Instituto de Alta Cultura.

Leal, João. 2000. Etnografias portuguesas (1870-1970): Cultura popular e identidade nacional [Portuguese Ethnographies (1870-1970): Folk Culture and National Identity]. Lisbon: Dom Quixote.

Leal, João. 2006. Antropologia em Portugal: Mestres, percursos, tradições [Anthropology in Portugal: Masters, Trajectories, Traditions]. Lisbon: Livros Horizonte.

Matos, Patrícia Ferraz de. 2006. As côres do império: Representações raciais no império colonial português [The Colours of Empire: Race Representations in the Colonial Empire]. Lisbon: Imprensa de Ciências Sociais.

Oliveira, Carlos Ramos. 2014. "Memória do Centro de Estudos de Antropologia Cultural [Centro de Estudos de Antropologia Cultural: A Brief Memorial].” Etnográfica 18 (2): 307-10.

Oliveira, Ernesto Veiga de, Fernando Galhano, and Benjamim Enes Pereira. 1976. Alfaia agrícola portuguesa [Portuguese Agricultural Tools]. Lisbon: Centro de Estudos Etnológicos. 
O’Neill, Brian J., and Joaquim Pai de Brito, eds. 1991. Lugares de Aqui: Actas do seminários “Terrenos Portugueses" [Places of Here: Annals of the Seminar "Portuguese Fields"]. Lisbon: Dom Quixote.

Pereira, Rui. 1998. "Introdução à Reedição [Introduction to the Revised Edition].” In Aspectos históricos e económicos [Historical and Economic Aspects]. Vol. 1 of Os Macondes de Moçambique [The Macondes of Mozambique], edited by Jorge Dias, v-lii. Lisbon: Comissão Nacional para as Comemorações dos Descobrimentos Portugueses/Instituto de Investigação Científica e Tropical.

Pereira, Rui. 2005. "Raça, sangue e robustez: Os paradigmas da antropologia física colonial portuguesa [Race, Blood and Fitness: The Paradigms of Portuguese Colonial Physical Anthropology]." Cadernos de Estudos Africanos 7/8: 209-41.

Pignatelli, Marina. 2014. "Antropologia em Portugal nos últimos 50 anos: Introdução [Anthropology in Portugal in the Last 50 Years: Introduction]." Etnográfica 18 (2): 301-5.

Pina-Cabral, João de. 1989. "Breves considerações sore o estado da antropologia em Portugal [Brief Notes on the State of Anthropology in Portugal]." Antropologia Portuguesa 7: 29-36.

Porto, Nuno. 2009. Modos de objectificação da dominação colonial: O caso do Museu do Dundo, 1940-1970 [Modes of Objectification of the Colonial Domination: The Case of Dundo Museum, 1940-1970]. Lisbon: Fundação Calouste Gulbenkian.

Roque, Ricardo. 2001. Antropologia e império: Fonseca Cardoso e a expedição à Índia em 1895 [Anthropology and Empire: Fonseca Cardoso and the 1895 India Expedition]. Lisbon: Imprensa de Ciencias Sociais.

Santos, Gonçalo Duro dos. 2005. A Escola de Antropologia de Coimbra, 1885-1950 [The School of Anthropology of Coimbra, 1885-1950]. Lisbon: Imprensa de Ciências Sociais.

Sobral, José Manuel. 2007. “O outro aqui tão próximo: Jorge Dias e a redescoberta de Portugal pela antropologia portuguesa [The Other Is So Close: Jorge Dias and Portuguese Anthropology's Rediscovery of Portugal]." Revista de História das Ideias 28: 479-526.

Vasconcelos, José Leite de. 1933-88. Etnografia Portuguesa [Portuguese Ethnography]. 10 vols. Lisbon: Imprensa Nacional.

Viegas, Susana de Matos, and João de Pina-Cabral. 2014. "Na encruzilhada Portuguesa: A antropologia contemporânea e a sua história [At the Portuguese Crossroads: Contemporary Anthropology and Its History]." Etnográfica 18 (2): 311-32.

West, Harry. 2004. "Inverting the Camel's Hump: Jorge Dias, His Wife, Their Interpreter and I." In Significant Others: Interpersonal and Professional Commitments in Anthropology. Vol. 10 of History of Anthropology, edited by Richard Handler, 51-90. Madison: University of Wisconsin Press. 